
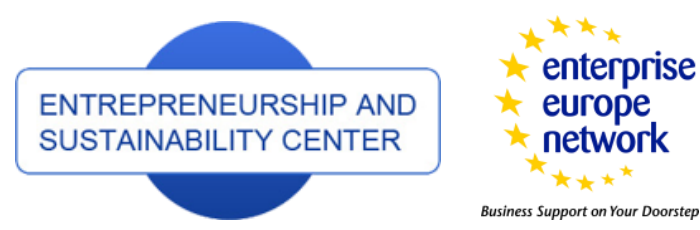

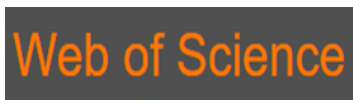

1 Clarivate

Publisher

http://jssidoi.org/esc/home

\title{
AN EVALUATION OF KNOWLEDGE MANAGEMENT SYSTEM'S COMPONENTS AND ITS FINANCIAL AND NON-FINANCIAL IMPLICATIONS
}

\author{
André Luhn' ${ }^{1}$, Sergey Aslanyan², Christian Leopoldseder ${ }^{3}$, Pamela Priess ${ }^{4}$ \\ 1,2,3,4 Pan-European University, Faculty of Economics and Business, \\ Tematínska 10, 851 05, Bratislava, Slovakia
}

E-mails: ${ }^{1}$ andre_luhn@web.de; ${ }^{2}$ s.a.aslanyan@gmail.com $;{ }^{3}$ Christian.Leopoldseder@assecosol.com; ${ }^{4}$ office@priessreal.at

Received 11 August 2017; accepted 20 November 2017; published 29 December 2017.

\begin{abstract}
Knowledge Management is an inclusive process of gathering knowledge, processing it and then utilising it in order to improve firm productivity and seek solutions to crucial problems. This paper is based on the assessment of structural framework of a Knowledge Management System (KMS) and how these components influence the financial and non-financial aspects of an organisation. The study mainly focuses on the evaluating the influence of KMS on the overall performance of SMEs in Austria. The current study investigates previous researches and theories to build a comprehensive understanding of the topic. It also conducts a quantitative analysis to evaluate the relationships between Knowledge Management Capabilities, Processes, and Firm Performance. To get first-hand information related to knowledge management practices, 126 managers and senior employees from 72 Austrian SMEs are surveyed. According to the results, KM capabilities have a significant positive relationship with KM processes. Moreover, KM processes in the Austrian SMEs have a significant positive influence on financial and non-financial performance. The study recommends increased focus on KM practices for improved overall performance.
\end{abstract}

Keywords: Knowledge Management Systems, Knowledge Management Capabilities, Knowledge Management Processes, Financial Performance, Non-Financial Performance, T-Shaped Skills, Learning Organisation, Correlation, Regression Analysis

Reference to this paper should be made as follows: Luhn, A.; Aslanyan, S.; Leopoldseder, Ch.; Priess, P. 2017. An evaluation of knowledge management system's components and its financial and non-financial implications, Entrepreneurship and Sustainability Issues 5(2): 315-329. http://doi.org/10.9770/jesi.2017.5.2(11)

JEL Classifications: G32, G41

Additional disciplines: information and communication

\section{Introduction}

Knowledge management is a well-structured procedure which includes retrieving knowledge from multiple sources and then processing this knowledge to extract useful information. This information is then utilised in order to improve the performance of a system and find innovative solutions to problems (Karagiannis and Reimer, 2005). Knowledge management also includes all the intentional and systematic methodologies applied for keeping the retrieved knowledge intact. The extensive evolution in the market has forced organisations to utilise their knowledge assets in order to win a competitive edge over other organisations (El-Said, 2015). Previous researches on knowledge management and its implementation have focused more on the factors that contribute 
towards successful knowledge management. Most of the previous research work explores the influence of knowledge management on the performance and competitiveness of an organisation (Hansen, 1999; Zander \& Kogut, 1995). However, there are very few research that focuses on assessment of the main components of a knowledge management system. The study of Lee and Choi (2003) proposed an integrated approach to evaluate knowledge management theories and identify the variables that are relevant to knowledge management system. Arora (2002) proposed that in order to assess the implications of a knowledge management system, it is very important to identify and evaluate all the components that are crucial for the success or failure of a KM system. This study focuses on the evaluation of knowledge management system's components and its financial and nonfinancial implications. In order to identify the core constructs of a KM system and understand the framework of a basic KM system, a literature review is included in the study, along with an empirical analysis. An important finding from the previous studies is utilised in order to set the direction of the current research study. The financial and non-financial implications of a knowledge management system are evaluated using statistical analysis. To assess the financial and non-financial implications of a KM system, a survey is designed for Small and Medium Enterprises (SMEs) in Austria which consists of all the important variables that are relevant to the topic of the current research. Responses from the participants are statistically modelled and analysed to generate important findings. The objective of the research study is to evaluate the main components of a KM system and assess their financial and non-financial implications in Small and Medium Enterprises in Austria. Therefore, the question under investigation is: "What is the impact of Knowledge Management Systems on the financial and non-financial performance of Austrian Small and Medium Enterprises?”

\section{Knowledge Management}

\subsection{Knowledge Management System - a Concept}

KMSs are not very popular among small and medium size entities because they are seen as costly and timeconsuming mechanisms and entities do not realise its importance and usefulness yet. However, the implementation by large organisations has attracted other entities to the benefits and importance of KMS (Lee, \& Hong 2002; Hislop, 2013). Therefore, the system is becoming popular and demanding with the passage of time. Knowledge management is the process through which companies increase the value of the gathered knowledge. There is often confusion between information management system and knowledge management system. The term "Information Management System" is generally referred to a software used to facilitate maintenance, retrieval, and transfer of information within the organisation. A Knowledge Information System (KMS) on the other hand is the system which helps the organisation to increase the potential of its intellectual capital (Armstrong \& Krebs, 2002).

Many entities do not find it useful to develop KMS for managing knowledge, but David William in his article stresses that organisations must deliberately develop KMS so that the knowledge consumed can be used at maximum (William, 2016a). Many scholars and researchers have presented with a various list of components that compose KMS but following are the 7 proposed elements combined by the author David William in his article that is must have for an entity to develop knowledge management system:

The first step is to make an effective strategy that identifies the opportunity or the problem, which can be used to improve the value or

Strategy intellectual asset. It includes the structure of policies and regulations that are organised in a specific manner so that areas at risk or with potential could be identified. 
ENTREPRENEURSHIP AND SUSTAINABILITY ISSUES

ISSN 2345-0282 (online) http://jssidoi.org/jesi/

2017 Volume 5 Number 2 (December)

http://doi.org/10.9770/jesi.2017.5.2(11)

A strategy is effective only if it is correctly implemented in the targeted areas and to do so the required duties should be distributed among the participants, they may include: supervisors; owners; managers; achievers; analysts etc.

Source of the Knowledge
To assess the authenticity of the knowledge, it is important to identify the source where it came from. Intellect is useful only if it comes from a reliable source, and is sufficient to facilitate the purpose. It is considered more reliable if the source is external (and authentic) since the chances of manipulation are lesser that way.

The functionality of a KMS is affected by the style, techniques, and mode of the system. The interface includes technology, people and structure style. Easing the users is a key element in enabling them to their full potential (William, 2016a). The interface reflects the type of organisation and is relevant in adopting a mode of processes.

Functions

There are dozens of possible functions that a KMS can be used for. Although they may differ from entity to entity, and depend on the nature, type and structure of organisation there are some which are most likely present in every KM system (William, 2016a). Some of the most common functions are: The identification of the problem or opportunity; Selection of critical part of the knowledge; Data Mining; Effective delivery of the knowledge; Refinement for enhancement of intellect value; Protecting of the preserves information; Maintenance to keep the knowledge up to date; and Application of the knowledge.

Infrastructure

This component refers to the flow of the process. It is vital that every concerned person should have clear access to the knowledge, and each participant must be exposed to only the part of knowledge which is designed for his/her review. The purpose of an effective infrastructure is to make sure that each participant is focused on his part of duties in the KMS. It is crucial that organisation uses right tools for the right process to facilitate the enhancement of the value of knowledge.

\section{Continuous Improvement}

KMS is not a one-time tool is used as a never-ending cycle for the organisation. Therefore, it is necessary that organisations keep improving their knowledge management system, so that any change in the process or entity model may not surprise KMS (William, 2016a). Improvements should be made to better the strategy, process, people and technology of the system.

Source: William (2016a); Choi and Lee (2002); McGinnis and Huang (2007); Holtshouse (2013)

On the other hand, KMS is also commonly divided among three components:

Capabilities - Covering the role of participants and continues improvement element. Processes - Include the sources, strategy, infrastructure, and interface of the system. 
Performance - Consist of the functionality of the KMS (Lee \& Lee, 2007).

\subsection{Non-Financial Benefits of Knowledge Management System}

\subsubsection{Decision- Making}

Decision making is a process which requires expertise, skills and sufficient knowledge organised in a meaningful order (Garfield, 2014). The primary function of KMS is to manage the information in such a way that the organisation can have maximum benefit from this intellect asset. The most likely usage of the outcome is the strategy or decision making. Managers, directors and top-level personnel rely on the available information for making strategic decisions. Therefore, it is necessary for them to know that the information they are basing their decisions is authentic, reliable, sufficient, and is fully understood before. Hence KMS assures all these and therefore facilitates decision-making capabilities to the organisation. Editor Lisa Quast has given the example of General Electric Inc. (an American conglomerate), who has put in place an additional committee Corporate Executive Council (CEC) as a form of knowledge management system (Quast, 2012).

\subsubsection{Builds Learning Organisation}

Author David Garvin believes that KMS is an important exercise for regular improvement. The need to learn more knowledge has enabled organisations to build a mindset that there is always the next step. This means that no matter how much an organisation has achieved, there is always room for improvement. The concept is basically applied to the employees of every level in the entity. Author has elaborated his logic by mentioning the US Army's After-Action Reviews (AARs), which are meant to take feedbacks from soldiers with the purpose of developing new techniques and resolving issues in the current ones. In this particular KMS system, each individual is enabled to observe his/her own weaknesses, assess their strengths and rate their performance. This is a good exercise for self-assessment which is of course reviewed by their seniors (Garvin, 2000; Liebowitz \& Frank, 2016). Hence, KMS helps in building learning opportunities in organisations.

\subsubsection{Stimulates Cultural Change and Innovation}

KMS is a useful tool for designing, describing or changing the culture of an organisation (Corfield \& Paton, 2016). If an entity allows a free flow of information, it may describe its structure as a casual organisation, allowing lower, mid and higher-level employees to coordinate with each other freely which may lead to innovations and change of ideas (Kane, 2014). The flow of knowledge or knowledge management is very important for any entity seeking a boost in its performance (King, Marks, 2008; Rajnoha et al., 2017). Making workplace as less stressful as possible through the creation of friendly and casual culture is a key to encouraging employees towards their jobs. The point is also covered in the notes of the author David Garvin, where he describes Change Acceleration Process (CAP) program as a successful attempt at creating a knowledge system to combine individuals for carving an innovative culture (Garvin, 2000); see also Ignatjeva et al. (2017).

\subsection{Financial Benefits of Knowledge Management System}

\subsubsection{Less Chance of Manipulation in the Financial Records}

An open environment with transparency is considered the ideal situation for the financial reporting. Organisations with unfair regulations and unnecessary restrictions give easy access to the top managerial personnel to manipulate the financials without a questioning authority. For example, if a chief financial officer (CFO) makes a mistake or deliberately acts against the interest of the company, he will very likely try to manipulate the financials in order to try and hide his mistakes or act of fraud (William, 2016b; Edvardsson \& Durst, 2013; Belás et al., 2017; Paseková et al., 2017). 
An effective KMS will probably highlight any such action, but if the boundaries in the organisation are too high with strict culture, it may be difficult for employees to challenge their superiors for their actions.

\subsubsection{Better Financial Reporting}

An effective KMS plays a key role in the constant flow of information without delays and fewer errors, since all the functions and relevant departments are integrated. The timely reporting is a crucial element of financial reporting system because a delay in sales or early recording of material transactions may cause disruptions in the reporting cycle making it difficult to justify to the external authorities (William, 2016b). The regular flow and constant checks enable smooth and timely financial reporting with fewer chances of errors.

\subsubsection{Trust of Investors}

Every investor appreciates transparency. KMs not only allow the internal individuals to access the information but also facilitate the external entities to get their desired information whenever they want. A proper working system with a constant flow of information results in timely response to investor's query; hence, results in increasing their confidence in companies (William, 2016b). Thereby, it can be affirmed that an effective KMS contributes to the elements necessary for the satisfaction of investors and other external parties (Like Tax authorities and auditors).

\section{Methodology}

\subsection{Research Approach}

The purpose of this research is to evaluate and assess the influence of KM processes and components on financial and non-financial performance aspects of Austrian SMEs. A quantitative research approach is adopted in this study, which appropriately addresses the research problem. Statistical methods and techniques are applied to process the data collected from SMEs.

A number of studies have already been conducted on the concept and implications of Knowledge Management. The purpose of research is identified on the basis of the exploration stage of the research. For early exploration, exploratory and descriptive purposes are appropriate. However, if the research is extending the findings of previous researches, the purpose of the research would be explanatory (Ivankova, Creswell \& Stick, 2006). This particular study is explanatory in nature, as it is extending previous researches on $\mathrm{KM}$ and its implications from the perspective of Austrian SMEs.

\subsection{Data Collection}

The research adopts a correlation and a descriptive design in order to analyse the primary data collected from the Austrian SMEs. According to Bordens (2006), correlation is an appropriate design to identify the relationship between two or more research variables and analyse their overall effect.

The data collection method used in this study is a questionnaire survey. 72 Austrian SMEs were targeted and a questionnaire was circulated in these firms. The survey questions were answered by 126 employees and managers working in various departments.

\subsection{Survey Measures}

All the variables of the survey questionnaire are based on multiple items. The use of multiple items for measuring the influence of a variable tends to generate more precise and accurate findings. These items are also used in the evaluation process in order to improve the reliability and credibility of the measurement process. The constructs 
ENTREPRENEURSHIP AND SUSTAINABILITY ISSUES

ISSN 2345-0282 (online) http://jssidoi.org/jesi/

2017 Volume 5 Number 2 (December)

http://doi.org/10.9770/jesi.2017.5.2(11)

are related to $\mathrm{KM}$ practices and processes implemented in an SME and their influence is observed on firm performance. A 5-point Liker scale is used to record responses of participants and relate these responses to the overall effect of KM on the organisation. Survey measurement on Likert-scale allows precise quantification of responses (Lee \& Choi, 2003).

\subsection{Survey Items}

The survey questionnaire used in this research is adopted from the study of Lee and Lee (2007). It consists of items relevant to the KM system and its components. All the items are related to various aspects of the SME performance, which are represented in the form of research constructs/variables. The table below shows the variables used in the survey and multiple items on the basis of which these constructs are analysed (Table 1):

Table 1. Knowledge Management System Components

\begin{tabular}{|c|c|c|}
\hline Variables & & Items \\
\hline \multirow{5}{*}{ Information Technology } & \multirow{5}{*}{ IT Support } & Information sharing via Intranet \\
\hline & & Knowledge map for knowledge source \\
\hline & & $\begin{array}{l}\text { Use of Customer Relationship Management } \\
\text { (CRM) }\end{array}$ \\
\hline & & Use of Data Warehouse \\
\hline & & IT support for information acquisition \\
\hline \multirow{5}{*}{ Organisation Culture } & \multirow{5}{*}{ Learning } & Clubbing and community gatherings \\
\hline & & Contents of job training \\
\hline & & Encouragement to attend seminars etc. \\
\hline & & Informal individual development \\
\hline & & Formal training programs \\
\hline \multirow{5}{*}{ Organisational Structure } & \multirow{5}{*}{ Centralization } & Making decisions without approval \\
\hline & & Supervisor's permission to act \\
\hline & & Need to refer others \\
\hline & & Making own decisions \\
\hline & & Acting without supervisor's consent \\
\hline \multirow{4}{*}{ People } & \multirow{4}{*}{ T-Shaped Skills } & Knowing core knowledge \\
\hline & & Employees expert in their tasks \\
\hline & & Employees can explain their task \\
\hline & & Employees having accurate know-how \\
\hline
\end{tabular}


ENTREPRENEURSHIP AND SUSTAINABILITY ISSUES

ISSN 2345-0282 (online) http://jssidoi.org/jesi/

2017 Volume 5 Number 2 (December)

http://doi.org/10.9770/jesi.2017.5.2(11)

The processes of knowledge management are an inclusive procedure and consist of multiple sub-processes like accessing knowledge, retrieving it, utilizing it and finally integrate it in all organisational procedures. The study has divided the construct of knowledge management system into 8 items (processes), presented in the Table 2 below:

Table 2. Knowledge Management System Components

\begin{tabular}{|l|l|}
\hline Construct & Items \\
\hline \multirow{5}{*}{ Knowledge management processes } & Accessing valuable knowledge \\
\cline { 2 - 2 } & Using knowledge that is accessible, in decisions \\
\cline { 2 - 2 } & Embedding knowledge in processes \\
\cline { 2 - 2 } & Facilitating growth of knowledge \\
\cline { 2 - 2 } & Generating new knowledge \\
\cline { 2 - 2 } & Determining the knowledge assets' value \\
\cline { 2 - 2 } & Transferring existing knowledge \\
\hline
\end{tabular}

The scorecard of knowledge management is finally used to evaluate the financial and non-financial implications of a KM system on Austrian SMEs. The study uses cognitive determinants in order to evaluate the financial and non-financial performances of organisations. The financial and non-financial performance variables and the relevant items are listed in the Table 3 below:

Table 3. Performance items

\begin{tabular}{ll}
\hline Construct & Items \\
\hline \multirow{3}{*}{ Financial Performance } & Greater Economic value added \\
\cline { 2 - 2 } & Greater Net Profit \\
\cline { 2 - 2 } & Greater Market Share \\
\cline { 2 - 2 } Non-Financial Performance & Greater Return on Investment \\
\cline { 2 - 2 } & More customer retention \\
\cline { 2 - 2 } & Greater customer satisfaction \\
\hline
\end{tabular}

\subsection{Research Variables}

There are three main constructs used in the research study: Capabilities, Processed and Performance.

\subsubsection{Capabilities}

A number of KM capabilities have been discussed in this study. The survey questionnaire addresses capabilities like information technology, organisation culture, organisational structure and people (Lee \& Lee, 2007). 
Knowledge is originated from people and propagates in an organisation through employees and managers and IT implementation. The penetration and utilization of knowledge depend on the organisation culture and structure.

\subsubsection{Processes}

The process of knowledge management is a complex procedure. It is based on various phases or sub-processes like accessing knowledge, retrieving it, utilizing it and finally integrating this knowledge in all organisational procedures.

\subsubsection{Performance}

The ability of an organisation to manage knowledge and utilize it for improving firm performance and problemsolving is reflected on the financial and non-financial performance of the organisation. The performance items in this research identify the financial and non-finical implications of a KM system implemented in SMEs.

\subsection{Research Model}

All the research variables and the relation between them are summarised in the research model presented below:

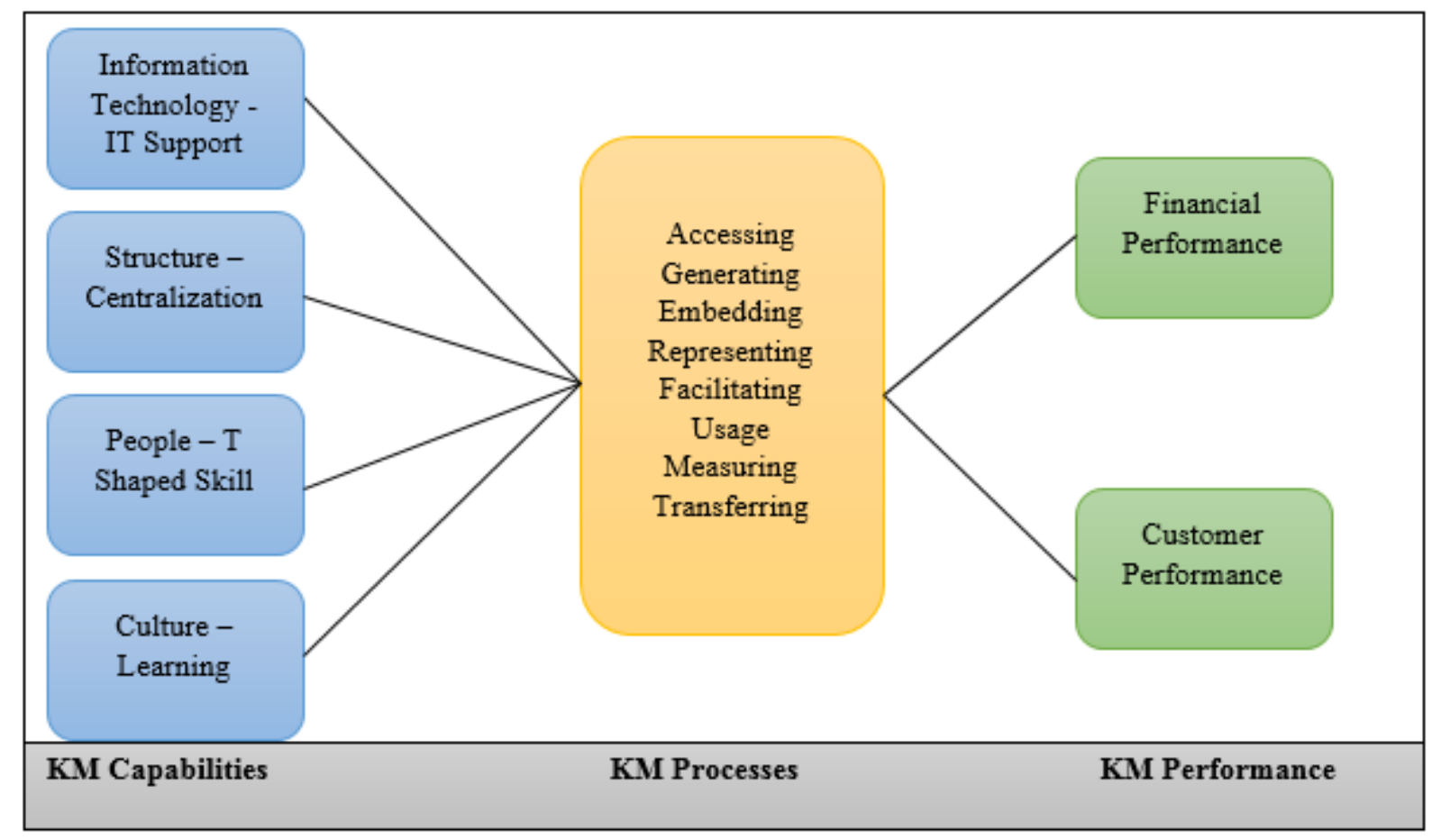

Figure 1. Research Model

\section{Results and Analysis}

The objective of this study is to examine the main components of a KM systems and assess their financial and non-financial implications in Small and Medium Enterprises in Austria. Before addressing the main research problem, descriptive analysis is conducted to explore the respondents' characteristics. Results reveal that majority of the respondents are working in the hospitality/tourism and wholesale/retail industry (21), followed by construction and engineering (18) (see Fig. 2). 


\section{Results and Analysis}

The objective of this study is to examine the main components of a KM systems and assess their financial and non-financial implications in Small and Medium Enterprises in Austria. Before addressing the main research problem, descriptive analysis is conducted to explore the respondents' characteristics. Results reveal that majority of the respondents are working in the hospitality/tourism and wholesale/retail industry (21), followed by construction and engineering (18) (see Fig. 2).

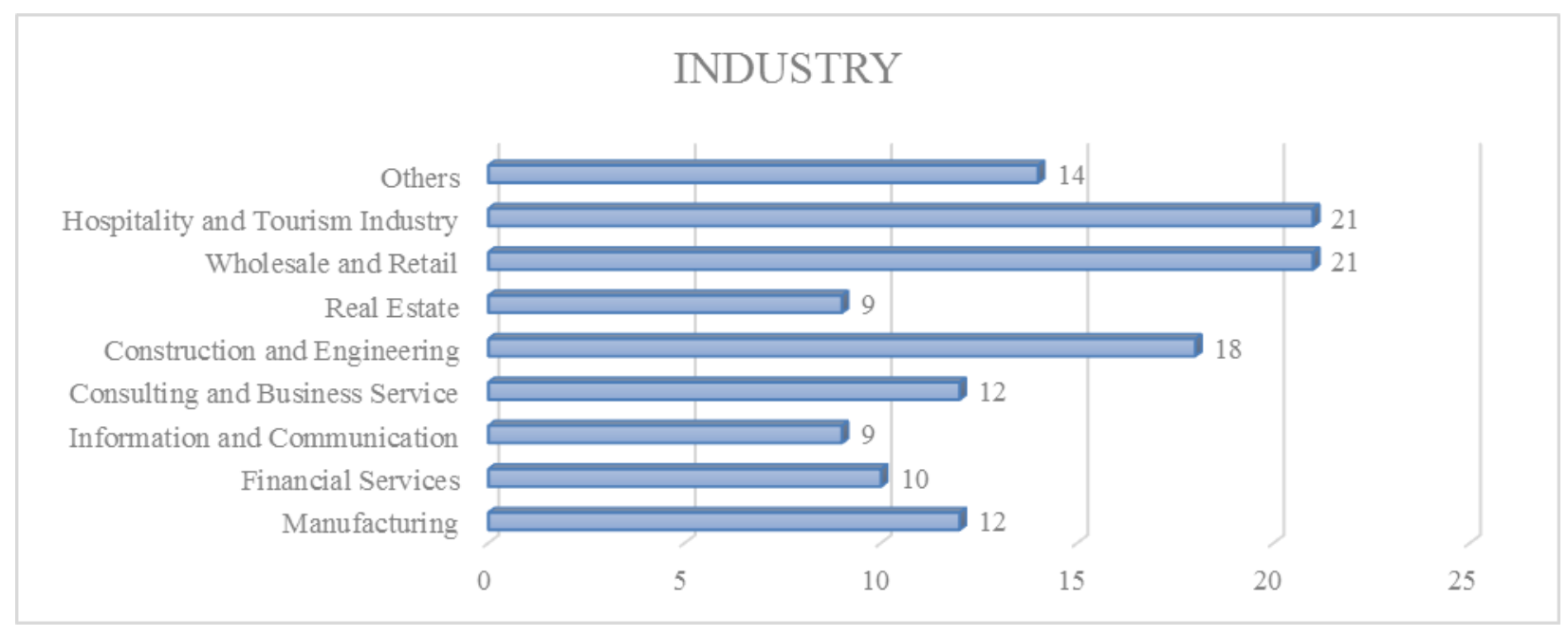

Figure 2. Respondents' Industry

Source: Author's own estimation

Moreover, the majority of the respondents are working in the accounting and finance departments in their organisations, which $19.8 \%$ of the total research participants. $16.7 \%$ of the managers/employees are working in personal management and training department, while $13.5 \%$ are part of the marketing department (Fig. 3).

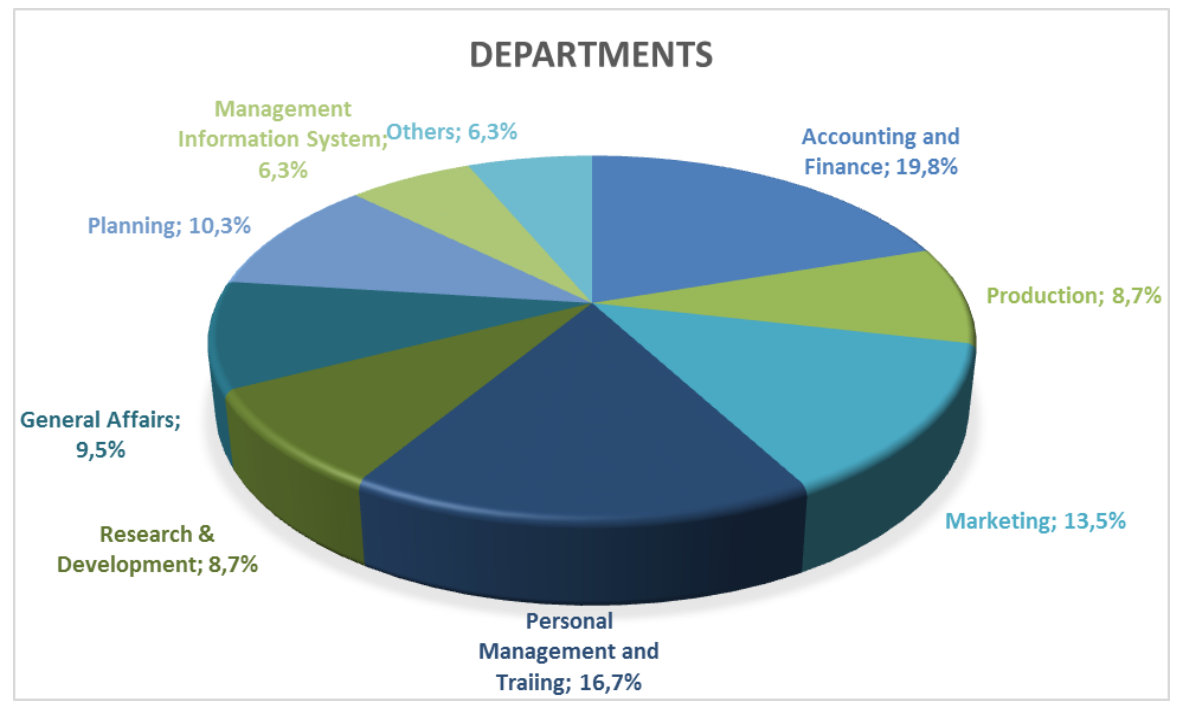

Figure 3. Respondents' Department Source: Author's own estimation 
Based on the data collected via questionnaire survey regarding KM Capabilities (information technology, organisational culture, organisational structure, and people), KM processes, and financial and non-financial performance, it is revelated that majority of the respondents perceive that their company employees have sufficient knowledge about their task and have the ability to explain their tasks to others (high t-shaped skills). The study found mixed results regarding the organisational structure of the companies, which suggests that the structure could either be centralised or decentralised. It is believed by the respondents that they have a learning organisation culture in their respective organisations. Moreover, they have sufficient IT support for information acquisition. In the context of KM processes, the majority agrees that their company stresses on generating new and accessing valuable knowledge. Their company also stresses on embedding knowledge in processes, products, and/or services. In addition, it is found that the companies focus on transferring existing knowledge to other parts of the organisation and stress on measuring the value of knowledge assets and the impact of knowledge management. It suggests that the selected Austrian SMEs have appropriate knowledge management processes.

The study has measured financial and non-financial implications through financial performance and customer satisfaction respectively. The internal consistency reliability of the research instrument is tested using Cronbach alpha statistic, which is found greater than the assumed threshold of 0.7. Moreover, the content validity of the questionnaire is measured through detailed analysis of previous KM practices. For determining the construct validity and summarising the observed variables (items), the techniques of principal component analysis (PCA) (factor analysis) is used. The KMO and Bartlett's test reveal that the sample is adequate $(\mathrm{KMO}=0.771)$ and the data is appropriate for running factor analysis (sig. < 0.001). The test extracts 7 factors/components that explain $89.7 \%$ of the cumulative variance (Fig. 4)

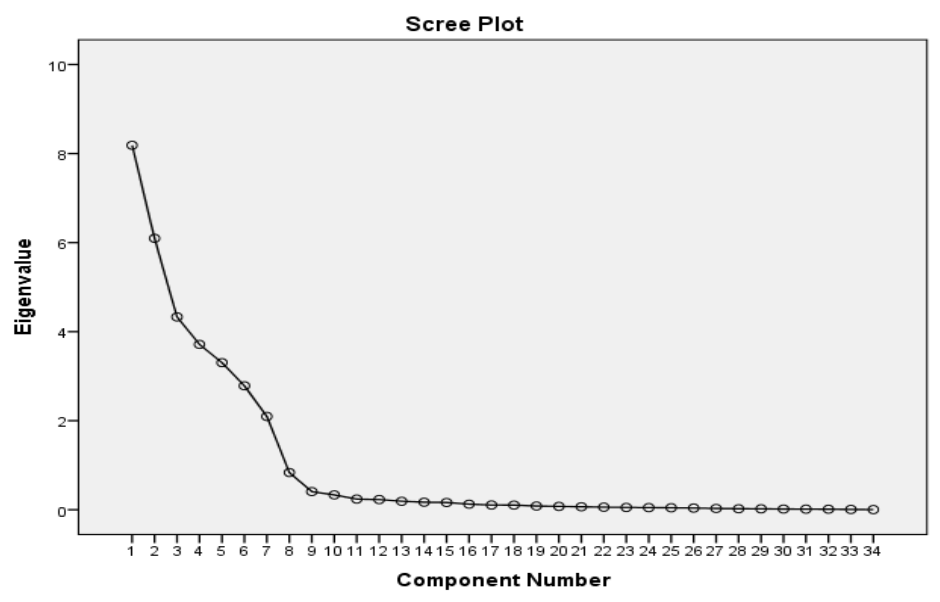

Figure 4. Scree Plot

Source: Author's own estimation

Using the PCA extraction method, and Varimax rotation method, the rotated component matrix is generated (see Table 3). The matrix shows the correlations between the variables and the estimated factors/components. 
ENTREPRENEURSHIP AND SUSTAINABILITY ISSUES

ISSN 2345-0282 (online) http://jssidoi.org/jesi/

2017 Volume 5 Number 2 (December)

http://doi.org/10.9770/jesi.2017.5.2(11)

Table 3. Factor Analysis

Source: Author's own estimation

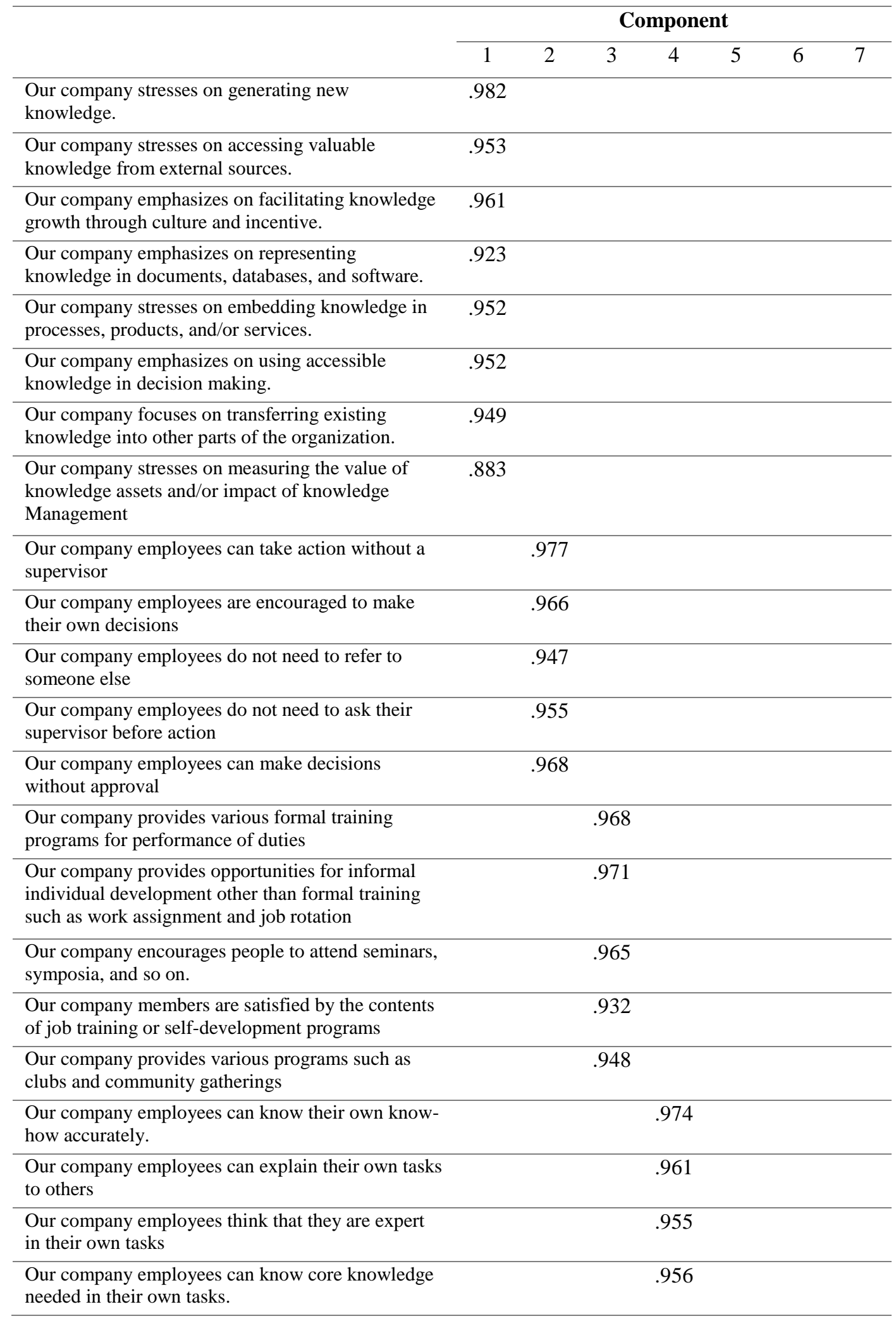


ENTREPRENEURSHIP AND SUSTAINABILITY ISSUES

ISSN 2345-0282 (online) http://jssidoi.org/jesi/

2017 Volume 5 Number 2 (December)

http://doi.org/10.9770/jesi.2017.5.2(11)

\begin{tabular}{lc}
\hline $\begin{array}{l}\text { Our company provides intranet for information } \\
\text { sharing }\end{array}$ & \\
\hline $\begin{array}{l}\text { Our company provides IT support (e.g., groupware) } \\
\text { for information acquisition }\end{array}$ & .955 \\
\hline $\begin{array}{l}\text { Our company provides Data Warehouse or } \\
\text { knowledge repository for knowledge acquisition }\end{array}$ & .950 \\
\hline $\begin{array}{l}\text { Our company provides 'knowledge map' for } \\
\text { knowledge source finding and accessing }\end{array}$ & .883 \\
\hline $\begin{array}{l}\text { Our company provides CRM - Customer } \\
\text { Relationship Management for customer information } \\
\text { gathering }\end{array}$ & \\
\hline $\begin{array}{l}\text { Compared with key competitors, our company has a } \\
\text { greater return on investment. }\end{array}$ & \\
\hline $\begin{array}{l}\text { Compared with key competitors, our company has a } \\
\text { greater market share. }\end{array}$ & \\
\hline $\begin{array}{l}\text { Compared with key competitors, our company has a } \\
\text { greater net profit. }\end{array}$ & .919 \\
\hline $\begin{array}{l}\text { Compared with key competitors, our company has a } \\
\text { greater economic value added. }\end{array}$ & .895 \\
\hline $\begin{array}{l}\text { Compared with key competitors, our company has } \\
\text { greater improvement in customer satisfaction. }\end{array}$ & .951 \\
\hline $\begin{array}{l}\text { Compared with key competitors, our company has } \\
\text { more creation of new customers. }\end{array}$ & \\
\hline $\begin{array}{l}\text { Compared with key competitors, our company has } \\
\text { more retention of current customers. }\end{array}$ & \\
\hline
\end{tabular}

Table 4 extracts 7 latent variables, which include KM capabilities, KM processes, financial performance and non-financial performance. In order to assess the relationships between the constructs of KM capabilities, KM processes, financial and non-financial performance, the tools correlation and regression analysis are used.

Table 4. Pearson Correlation Source: Author's own estimation

\begin{tabular}{|c|c|c|c|c|c|c|}
\hline \multicolumn{7}{|c|}{ Correlations } \\
\hline & & TS & $\mathrm{C}$ & $\mathrm{LC}$ & IS & KMP \\
\hline \multirow[t]{3}{*}{ T-Skills } & Pearson Correlation & 1 & $.254^{* *}$ & $.306^{* *}$ & $.236^{* *}$ & $.289^{* * *}$ \\
\hline & Sig. (2-tailed) & & .004 & .001 & .008 & .001 \\
\hline & $\mathrm{N}$ & 126 & 126 & 126 & 126 & 126 \\
\hline \multirow[t]{3}{*}{ Centralization } & Pearson Correlation & $.254^{* *}$ & 1 & $.409^{* *}$ & $.184^{*}$ & $.451^{* * *}$ \\
\hline & Sig. (2-tailed) & .004 & & .000 & .039 & .000 \\
\hline & $\mathrm{N}$ & 126 & 126 & 126 & 126 & 126 \\
\hline \multirow[t]{3}{*}{ Learning Culture } & Pearson Correlation & $.306^{* *}$ & $.409^{* *}$ & 1 & $.344^{* *}$ & $.701^{* *}$ \\
\hline & Sig. (2-tailed) & .001 & .000 & & .000 & .000 \\
\hline & $\mathrm{N}$ & 126 & 126 & 126 & 126 & 126 \\
\hline \multirow[t]{2}{*}{ IT Support } & Pearson Correlation & $.236^{* *}$ & $.184^{*}$ & $.344^{* *}$ & 1 & $.598^{* *}$ \\
\hline & Sig. (2-tailed) & .008 & .039 & .000 & & .000 \\
\hline
\end{tabular}


ENTREPRENEURSHIP AND SUSTAINABILITY ISSUES

ISSN 2345-0282 (online) http://jssidoi.org/jesi/

2017 Volume 5 Number 2 (December)

http://doi.org/10.9770/jesi.2017.5.2(11)

\begin{tabular}{|l|l|r|r|r|r|r|}
\hline \multirow{2}{*}{ KM Processes } & $\mathrm{N}$ & 126 & 126 & 126 & 126 & 126 \\
& Pearson Correlation & $.289^{* *}$ & $.451^{* *}$ & $.701^{* *}$ & $.598^{* *}$ & 1 \\
\hline & Sig. (2-tailed) & .001 & .000 & .000 & .000 & 126 \\
\hline & $\mathrm{N}$ & 126 & 126 & 126 & 126 & \\
\hline **. Correlation is significant at the 0.01 level (2-tailed). & & & \\
*. Correlation is significant at the 0.05 level (2-tailed).
\end{tabular}

According to the table 4, each of the four KM capabilities is significantly correlated at 0.01 and 0.05 level with each other. Moreover, the KM capabilities have significant positive correlation with KM processes at 0.01 level. It suggests that a focus on IT, organisational structure, organisational culture, and people as KM capabilities in Austrian SMEs positively affects KM processes within the organisations.

The impact of KM processes is further examined on the financial and non-financial performance of Austrian SMEs using simple linear regression (see Table 5). The proposed regression models can be mathematically described as:

$$
\begin{gathered}
\mathrm{FP}=\alpha_{1}+\beta_{1}(\mathrm{KMP}) \text {--- } \mathrm{NFP}=\alpha_{2}+\beta_{2}(\mathrm{KMP}) \text {--- } \\
\mathrm{NF}
\end{gathered}
$$

Where FP, NFP, and KMP represent, financial performance, non-financial performance, and knowledge management processes. Here, KMP is the independent variable or predictor, while FP and NFP are the dependent variables which are analysed in two separate regression equations. $\alpha$ is the constant term, whereas $\beta$ is the coefficient which explains the rate of change in the dependent variable.

Table 5. Regression Analysis

Source: Author's own estimation

\begin{tabular}{lcccccc}
\hline & \multicolumn{7}{c}{ Financial Performance } & \multicolumn{2}{c}{ Non-Financial Performance } \\
\hline & B & $\mathbf{t}$ & Sig. & B & $\mathbf{t}$ & Sig. \\
& & & & & & \\
\hline (Constant) & 2.774 & 5.459 & .000 & 3.213 & 7.699 & .000 \\
\hline KM Processes & .296 & 2.392 & .018 & .223 & 2.191 & .030 \\
\hline
\end{tabular}

The table 4.3 reveals that at 0.05 level of significance the impact of KM processes (accessing valuable knowledge, using knowledge in decisions, embedding knowledge in processes, representing knowledge in documents, facilitating growth of knowledge, generating new knowledge, determining the knowledge assets' value and transferring existing knowledge) is statistically significant in explaining financial and non-financial performance. It may suggest that KM processes influence financial performance by enhancing return on investment, market share, net profit, and economic value added. Moreover, KM processes may impact non-financial performance by improving customer satisfaction, creating new customers, and retaining existing customers.

The proposed regression equations ( 1 and 2), based on the regression results, can be written as:

$$
\begin{gathered}
\mathrm{FP}=2.774+0.296(\mathrm{KMP}) \\
\mathrm{NFP}=3.213+0.223(\mathrm{KMP})
\end{gathered}
$$


ENTREPRENEURSHIP AND SUSTAINABILITY ISSUES

ISSN 2345-0282 (online) http://jssidoi.org/jesi/

2017 Volume 5 Number 2 (December)

http://doi.org/10.9770/jesi.2017.5.2(11)

\section{Conclusion}

The research study evaluated the main components of a KM systems and assessed their financial and nonfinancial implications in SMEs in Austria. It adopted a quantitative research methodology and used statistical tools to analyse the problem. The results showed that the Austrian SMEs have high KM capabilities in terms of tshaped skills, learning organisational culture and IT support. They also have appropriate knowledge management processes. The correlation analysis revealed that the KM capabilities have significant positive correlation with KM processes in Austrian SMEs. Moreover, KM processes in the organisations have a significant positive influence on financial and non-financial performance.

These results of the study suggest that the SMEs in Austria need to focus more on practices and processes related to knowledge management, which can help them in improving their overall performance. However, at the same time, it is difficult to generalise the results of the study on the entire population of SMEs in Austria. Therefore, future research on the subject should increase the sample size in order to achieve more reliable results.

\section{References}

Armstrong, C., \& Krebs, V. (2002). U.S. Patent Application No. 10/138,172.

Arora, R. (2002). Implementing knowledge management - a balanced scorecard approach. Journal of Knowledge Management, 6(2), 240249. https://doi.org/10.1108/13673270210434340

Belás, J.; Mišanková, M.; Schönfeld, J.; Gavurova, B. 2017. Credit risk management: financial safety and sustainability aspects, Journal of Security and Sustainability Issues 7(1): 79-93. https://doi.org/10.9770/jssi.2017.7.1(7)

Bordens, K. (2006). Research Design \& Methods. New Delhi: Tata McGraw-Hill.

Choi, B., \& Lee, H. (2002). Knowledge management strategy and its link to knowledge creation process. Expert Systems with applications, 23(3), 173-187. http://citeseerx.ist.psu.edu/viewdoc/download?doi=10.1.1.98.9061\&rep=rep1\&type=pdf

Corfield, A., \& Paton, R. (2016). Investigating knowledge management: can KM really change organisational culture? Journal of Knowledge Management, 20(1), 88-103. https://doi.org/10.1108/JKM-12-2014-0502

Edvardsson, I. R., \& Durst, S. (2013). The benefits of knowledge management in small and medium-sized enterprises. Procedia-social and behavioral sciences, 81, 351-354. https://doi.org/10.1016/j.sbspro.2013.06.441

El-Said G. R. (2015). Understanding Knowledge Management System Antecedents Of Performance Impact: Extending The TaskTechnology Fit Model With Intention To Share Knowledge Construct. Future Business Journal. Faculty of Commerce and Business Administration, Future University. https://doi.org/10.1016/j.fbj.2015.11.003

Garfield, S. (2014) .15 Knowledge Management Benefits.

Garvin, D. (2000). To move ahead one must often first look behind. Page 106 \& 125.

Hansen, M.T. (1999). The Search-Transfer Problem: The Role of Weak Ties in Sharing Knowledge across Organisation Subunits. Administrative Science Quarterly, 44(1), 82-111. https://doi.org/10.2307/2667032

Hislop, D. (2013). Knowledge management in organisations: A critical introduction. Oxford University Press.

Holtshouse, D. K. (2013). Information technology for knowledge management. Springer Science \& Business Media.

Ignatjeva, S.; Volosnikova, L.; Efimova, G. 2017. Assessment of inclusive educational space in higher education institution. Journal of Security and Sustainability Issues, 7(1), 123-132. https://doi.org/10.9770/jssi.2017.7.1(10) 
ENTREPRENEURSHIP AND SUSTAINABILITY ISSUES

ISSN 2345-0282 (online) http://jssidoi.org/jesi/

2017 Volume 5 Number 2 (December)

http://doi.org/10.9770/jesi.2017.5.2(11)

Ivankova, N. V., Creswell, J. W., \& Stick, S. L. (2006). Using mixed-methods sequential explanatory design: From theory to practice. Field Methods, 18(1), 3-20. http://journals.sagepub.com/doi/abs/10.1177/1525822X05282260

Kane, J. (2014). 8 Benefits of Having a Knowledge Management Strategy. Life Sciences, Information management.

Karagiannis D. \& Reimer U. (2005). Practical Aspects of Knowledge Management: 5th International Conference, PAKM 2004, Vienna, Austria.

King, W. R., \& Marks, P. V. (2008). Motivating knowledge sharing through a knowledge management system. Omega, 36(1), 131-146. https://doi.org/10.1016/j.omega.2005.10.006

Lee, H., \& Choi, B. (2003). Knowledge Management Enablers, Processes, and Organisational Performance: An Integrative View and Empirical Examination. Journal of Management Information Systems, 20(1), 179-228. http://www.ceri.msu.edu/publications/pdf/T-Shaped_Skills_2.pdf

Lee, S. M., \& Hong, S. (2002). An enterprise-wide knowledge management system infrastructure. Industrial Management \& Data Systems, 102(1), 17-25. https://doi.org/10.1108/02635570210414622

Lee, Y. \& Lee, S. (2007). Capabilities, Processes, and Performance of Knowledge Management: A structural approach. Inter-Science

Lee, Y. C., \& Lee, S. K. (2007). Capabilities, processes, and performance of knowledge management: A structural approach. Human Factors and Ergonomics in Manufacturing \& Service Industries, 17(1), 21-41. https://doi.org/10.1002/hfm.20065

Liebowitz, J., \& Frank, M. (Eds.). (2016). Knowledge management and e-learning. CRC press.

McGinnis, T. C., \& Huang, Z. (2007). Rethinking ERP success: A new perspective from knowledge management and continuous improvement. Information \& Management, 44(7), 626-634. https://doi.org/10.1016/j.im.2007.05.006

Paseková, M.; Svitaková, B.; Kramá, E.; Otrusinová, M. 2017. Towards financial sustainability of companies: issues related to reporting errors. Journal of Security and Sustainability Issues, 7(1), 141-153. https://doi.org/10.9770/jssi.2017.7.1(12)

Rajnoha, R.; Korauš, A.; Dobrovič, J. 2017. Information systems for sustainable performance of organizations. Journal of Security and Sustainability Issues 7(1), 167-179. https://doi.org/10.9770/jssi.2017.7.1(14)

Quast, L. (2012). Why knowledge management is important to the success of your company. https://www.forbes.com/sites/lisaquast/2012/08/20/why-knowledge-management-is-important-to-the-success-of-yourcompany/\#448085b73681

William, D. (2016a). ABCs of KM. Components of a knowledge management system. https://realkm.com/2016/02/03/components-of-aknowledge-management-system/

William, D. (2016b). Knowledge Management System. A model for understanding knowledge systems.

Zander, D., \& Kogut, B. (1995). Knowledge and the speed of the transfer and imitation of organisational capabilities: An empirical test. Organisation Science, 6(1), 76-92.

https://www0.gsb.columbia.edu/faculty/bkogut/files/1995_OrgSci_Zander_Kogut.pdf

Copyright (C) 2017 by author(s) and VsI Entrepreneurship and Sustainability Center

This work is licensed under the Creative Commons Attribution International License (CC BY).

http://creativecommons.org/licenses/by/4.0/

(c) (7) Open Access 